\title{
A STUDY OF FACTORS INFLUENCING THE FORMATION OF HARMFUL DEPOSITS IN THE DIESEL ENGINE INJECTORS
}

\section{BADANIE CZYNNIKÓW WPŁYWAJĄCYCH NA TWORZENIE SZKODLIWYCH OSADÓW WTRYSKIWACZY PALIWA SILNIKÓW Z ZAPŁONEM SAMOCZYNNYM*}

\begin{abstract}
The paper describes various types of deposits of injectors used in CI engines with direct and indirect fuel injection. Various factors have been determined which affect the formation and size of deposits. These factors have also been classified and evaluated in terms of their impact on the formation of deposits precursors and further changes of deposits during the engine life. The results of deposits formation tests have been presented. The external and internal deposits in the High Pressure Common Rail fuel injection systems have been photographed and described. The impact of formed deposits on the diagnostic parameters of injectors has been discussed broadly as it determines the range of injectors' dysfunction and their fit for further use.
\end{abstract}

Keywords: compression ignition engines, fuel injectors, external injector deposits, internal injector deposits, hazards caused by deposits.

\begin{abstract}
$W$ artykule opisano różne typy osadów wtryskiwaczy silników ZS z pośrednim i bezpośrednim wtryskiem paliwa. Określono różnorodne czynniki mające wpływ na tworzenie i zmiany wielkości osadów. Dokonano też klasyfikacji i oceny znaczenia przedmiotowych czynników na powstawanie prekursorów osadów oraz dalsze zmiany osadów w czasie eksploatacji silnika. W zakresie opisu przeprowadzonych badań przedstawiono wyniki procesów tworzenia osadów w warunkach testów silnikowych. Utworzone $w$ ten sposób osady zewnętrzne $i$ wewnętrzne wtryskiwaczy układu wysokociśnieniowego wtrysku paliwa typu common rail byty następnie udokumentowane fotograficznie, oraz opisane. Szeroko omówiono też wyniki oceny wpływu wytworzonych osadów wtryskiwaczy na zmiany ich parametrów diagnostycznych, określających zakres dysfunkcji wtryskiwaczy i decydujacych o możliwości ich dalszego stosowania.
\end{abstract}

Stowa kluczowe: silniki z zapłonem samoczynnym, wtryskiwacze paliwa, osady zewnętrzne wtryskiwaczy, osady wewnętrzne wtryskiwaczy, zagrożenia powodowane osadami.

\section{Preface}

The worldwide studies on the formation mechanisms and prevention of deposits in fuel injectors in CI (compression ignition) and SI (spark ignition) engines have been conducted for almost twenty years. The hazards caused by the formation of external (coke) deposits on pintle injectors in CI engines with indirect injection were recognized already in 1990s. The fouling with coke deposits was found on the fuel outflow channel and also on the area around the edge of fuel outlet hole and the cylindrical part of pintle nozzle mating with the fuel injection hole. In case of this type of injectors and indirect injection CI engines, the size and speed of coke deposit formation on injector atomizers is more influenced by the type (design) of the injector itself than by the fuel. The formation process of organic coke deposits is a result of thermal decomposition of fuel during combustion, and the size of deposits can be controlled to some degree by adding detergent-dispersant additives to the fuel. These issues were broadly described by, inter alia, Barker, Snape and Scurr [2], Quigeley, Barbour, Arters and Bush [11], Lacey, Gail, Kientz, Milanovic and Gris [9], and Żak, Ziemiański, Stępień and Wojtasik [19]. On the other hand, in the HPCR (High Pressure Common Rail) injectors, the coke deposits form around and on the edges of fuel outlet holes, but also on the walls inside the fuel channels of injector atomizers. These are usually a mixture of organic and inorganic deposits. Taking into account the fact that the inside diameter of a fuel channel is less than $0.1 \mathrm{~mm}$, the deposits distort the stream of atomized fuel and change its range with an adverse effect on atomization and mixing of fuel with air in combustion chambers as reported by: Birgel et al. [3, 4], Caprotti et al. [5, 6], Quigeley et al. [10] and Stępień [14]. Uncontrolled changes of excess air number in the fuel-air mixture combined with an insufficient atomization of the fuel streams and mixing with exhaust gases at incorrect proportions by the EGR system leads to incomplete combustion. The result is lower engine performance, uneven running, increased emissions of exhaust gases and fuel consumption. The longer range of streams can cause washing the combustion chamber walls with liquid fuel, and this as a result of incomplete fuel evaporation in the air charge leads to incomplete combustion and increased emissions of pollutants, particularly HC. The results of studies conducted by Stępien [15] showed that in the extreme case the deposits formed inside the fuel channels can totally obstruct the hole, particularly when the engine is often stopped and cooled during the operation which allows the deposits to stabilize - Fig. 1.

A very high pressure in the HPCR injection systems, reaching even $300 \mathrm{MPa}$, allows a very good fuel atomization in the stream injected to the combustion chamber but also causes a significant fuel temperature increase during a rapid depressurization after the fuel squeezes (seeps) through leaks between the injector's mating parts. This, in combination with contaminants which make their way into to the fuel during its production, distribution and storage (particularly metallic elements with catalytic properties), chemical reactions taking place between some fuel additives and biocomponents (FAME) which

(*) Tekst artykułu w polskiej wersji językowej dostępny w elektronicznym wydaniu kwartalnika na stronie www.ein.org.pl 
a)

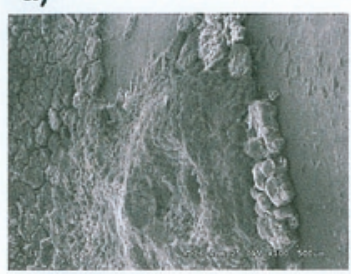

b)

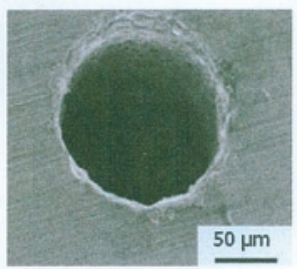

e)

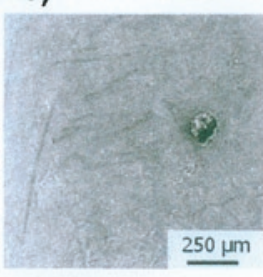

d)

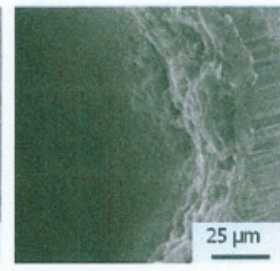

f)

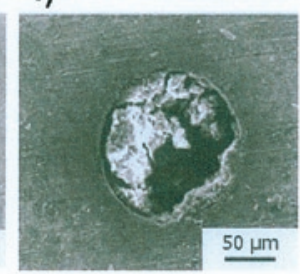

Fig. 1. External coke deposits on an HPCR injectors a) coke deposits formed around the fuel outlet hole $b, c, d)$ coke deposits formed at the hole edge and inside the channel e, f) coke deposits obstructing the hole

contribute to a reduction of the fuel oxidation stability, leads to the formation of the Internal Diesel Injector Deposits (IDID).

These deposits are divided into a few types and are classified according to various criteria, most frequently by composition determined by means of the FT-IR (Fourier Transform Infrared Spectroscopy) - Table 1. Sometimes the IDID are analysed using other techniques, e.g. SEM (Scanning Electron Microscopy) and EDS (Energy

Dispersive X-Ray Spectroscopy), and based on the results they are divided into types (see Yamada et al. [18], Tanaka et al. [16], and Fang and McCormick [7]). That is why various publications use different names for the same deposit types and the number of IDID types differs between authors. Nonetheless, these are always the same deposits from the point of view of composition and formation mechanisms [2, $14,16]$. This has been a motivation for an attempt to systemize the deposit types and factors which influence their formation.

Table 1 presents various types of deposits linked with the factors which influence their formation and size. The table also includes an evaluation of the factors in terms of their impact on the formation of deposit precursors and further changes of deposits during the engine life. Table 1 indicates a large number of varying factors that may affect to a greater or lesser degree the formation of deposits and the size change over time. Some of these factors have an opposing impact on various deposits in different fuel injection systems. For instance, the PIBSI (Polyisobutylene Succinimide) detergent additives widely used in the 1990 s prevent the formation of internal coke deposits in pintle injectors in the indirect injection engines. At the same time, such additives are not always effective in preventing the formation of external deposits in modern HPCR systems, and in combination with lubrication additives can cause the formation of polymer amide deposits of the IDID type, particularly in case of PIBSI with small molecular mass, as indicated by Reid and Barker [12].

One of the most important factors causing the formation of deposits in fuel injectors is the fuel oxidation. The content of FAME in fuel has a significant impact on reduction of the fuel oxidation stability. As a result, the oxidation stability of pure FAME is different than of its mixture with diesel fuel at different proportions. In case of engines with indirect fuel injection, where the injector operating temperature is much lower than in the HPCR systems in the HSDI (High Speed Direct Injection) engines, FAME, being a polar solvent, can wash out coke deposits from injectors, particularly at low engine loads [11]. FAME, however, behaves quite differently in modern engines with the HPCR injection systems, with high operating temperatures and

Table 1. Classification of factors influencing the formation of deposits in CI engine injectors

\begin{tabular}{|c|c|c|c|c|c|c|c|c|}
\hline & & & \multicolumn{2}{|c|}{ External injector deposits } & \multicolumn{4}{|c|}{ Internal injector desists } \\
\hline & & & $\begin{array}{l}\text { Indirect } \\
\text { injection }\end{array}$ & $\begin{array}{l}\text { Direct injection } \\
\text { engines }\end{array}$ & \multicolumn{4}{|c|}{ Direct injection engines } \\
\hline \multicolumn{3}{|c|}{ Deposit type and place of formation } & $\begin{array}{l}\text { Coke deposits } \\
\text { (organic) }\end{array}$ & $\begin{array}{l}\text { Coke deposits } \\
\text { (organic and } \\
\text { inorganic) }\end{array}$ & $\begin{array}{c}\text { Carboxylates } \\
\text { (with large } \\
\text { molecular } \\
\text { mass) }\end{array}$ & Amides & $\begin{array}{l}\text { Esters } \\
\text { (FAME type) }\end{array}$ & $\begin{array}{c}\text { Esters } \\
\text { (CFI type - Cold } \\
\text { Flow Improver) }\end{array}$ \\
\hline \multicolumn{3}{|c|}{$\begin{array}{l}\text { Factors influencing the formation of } \\
\text { deposits }\end{array}$} & \multicolumn{6}{|c|}{$\begin{array}{l}\text { Impact on the formation and size of deposits } \\
\text { (xxx-large / } x x-\text { medium / } x-\text { small } / 0 \text { - insignificant } / \text { - not applicable) }\end{array}$} \\
\hline \multirow{8}{*}{ Fuel } & $\begin{array}{c}\text { Composition of } \\
\text { base fuel }\end{array}$ & $\begin{array}{l}\text { Content of O2, } \\
\text { N2 and S }\end{array}$ & $x x$ & $x x x$ & $x x$ & XX & $\mathrm{X}$ & $x$ \\
\hline & \multirow{5}{*}{ Additives } & $\begin{array}{c}\text { Detergent } \\
\text { (PIBSI-based) }\end{array}$ & $\mathbf{x X}$ & $\mathbf{x X X}$ & 0 & $x X X$ & 0 & 0 \\
\hline & & Lubrication & 0 & $\mathbf{X}$ & $\mathbf{X X X}$ & $\mathbf{X X X}$ & $\mathbf{X X}$ & $\mathbf{x}$ \\
\hline & & $\begin{array}{l}\text { Corrosion } \\
\text { inhibitors }\end{array}$ & 0 & $x$ & $x x x$ & 0 & $x$ & $x$ \\
\hline & & $\begin{array}{l}\text { Increasing the } \\
\text { cetane number }\end{array}$ & $\mathbf{x}$ & $\mathbf{x}$ & 0 & 0 & $x x$ & $x$ \\
\hline & & CFI & 0 & 0 & 0 & 0 & 0 & $\mathbf{X X X}$ \\
\hline & Contaminants & $\begin{array}{c}\mathrm{Zn}, \mathrm{Cu}, \mathrm{Na}, \mathrm{K} \\
\mathrm{Ca}, \mathrm{Cl}, \mathrm{Mg}\end{array}$ & $x x$ & $x x x$ & $x x x$ & $x$ & 0 & 0 \\
\hline & Biocomponents & FAME & $\mathbf{X X}$ & $\mathbf{X X}$ & 0 & 0 & $\mathbf{X X X}$ & 0 \\
\hline \multirow{3}{*}{$\begin{array}{l}\text { Engine } \\
\text { and fuel } \\
\text { injection } \\
\text { system }\end{array}$} & \multirow[b]{2}{*}{ Fuel injection } & Injector design & $\mathbf{X X X}$ & $\mathbf{x}$ & $x x$ & $x x$ & $x x$ & $x x$ \\
\hline & & $\begin{array}{l}\text { Operation } \\
\text { parameters } \\
\text { (HPCR) }\end{array}$ & - & $\mathbf{x x}$ & $\mathbf{x}$ & $x x$ & $x x$ & $x x$ \\
\hline & Systems & EGR, Blow-by & $x$ & $\mathbf{X X}$ & 0 & 0 & 0 & 0 \\
\hline \multirow{4}{*}{$\begin{array}{l}\text { Operating } \\
\text { conditions }\end{array}$} & \multirow{4}{*}{ Engine load } & Low & $X X$ & $\mathrm{X}$ & $x X$ & $x$ & $x$ & $x$ \\
\hline & & High & $x$ & $X X$ & $x$ & $X X$ & $\mathbf{X X}$ & $\mathbf{X X}$ \\
\hline & & $\begin{array}{l}\text { Dynamic } \\
\text { changes }\end{array}$ & $x$ & $x$ & $x$ & $x$ & $x$ & $x$ \\
\hline & & Long stoppages & $\mathbf{x}$ & $\mathbf{X X X}$ & $\mathbf{X X}$ & $\mathbf{X X}$ & $\mathbf{X X}$ & $\mathbf{X X}$ \\
\hline
\end{tabular}


pressures, where fuel heated up to $60{ }^{\circ} \mathrm{C}$ returns many times from the injection systems overflows to the fuel tank, heating up the whole fuel system. Such conditions significantly accelerate the FAME degradation process by oxidation of unsaturated FAME bonds to the peroxide structures which transform into acids and aldehydes. The peroxide structures can also react with other FAME molecules, forming dimers. This can lead to the formation of oligomers which are precursors of the deposits formation if their molecular mass and polarity are sufficiently high. In addition, Fang and McCormick in their studies discovered that the largest deposits are formed in case of mixtures containing from $20 \%(\mathrm{v} / \mathrm{v})$ to $30 \%(\mathrm{v} / \mathrm{v})$ of FAME in the diesel fuel [7]. The reason is that the deposits formed from oligomers are highly polar and better soluble in polar FAME, and poorly soluble in hydrocarbons. When the FAME content exceeds $50 \%(\mathrm{v} / \mathrm{v})$ the fuel becomes sufficiently polar to dissolve deposits formed in the injection system. When the FAME concertation in the fuel is too low $(<5 \%(\mathrm{v} / \mathrm{v}))$, there are not enough oligomers to form the deposits. The fuel containing from $20 \%(\mathrm{v} / \mathrm{v})$ to $30 \%(\mathrm{v} / \mathrm{v})$ of FAME is not sufficiently polar and the oligomers precipitate, forming deposits $[7,11]$.

The studies conducted to date clearly indicate that trace content of some elements, mostly metallic, accelerate the formation of external and internal deposits (IDID) in injectors, and $\mathrm{Zn}$ and $\mathrm{Cu}$ to a greater degree intensify the formation of external deposits, and $\mathrm{Na}, \mathrm{Cl}, \mathrm{K}, \mathrm{Ca}$ and $\mathrm{Mg}$ the formation of IDID, as indicated by the results of studies by Iida [8], Lacey et al. [9] and Shiotani and Goto [13].

Forces between the surface material and the deposit (adhesion) play an important part in keeping the deposits on the surface where they have formed. This applies particularly to the IDID which form on the injector parts that make sliding movements relative to each other. The deposits in these places slow down the injector operation, and consequently can change not only the amount of fuel dosed in a single injection, but also in an uncontrolled way they can alter the time of start and end and duration of individual phases in multiple injection. The result is that the amount of fuel injected to individual cylinders is not equal, and the quality of fuel-air mixture in combustion chambers is not uniform. In case of carboxylate, amide and CFI (Cold Flow Improver) polymer deposits, the adhesion of deposits to the surface is a result of intramolecular forces, and in case of the deposits related to the FAME degradation the chemical bonds come into play as described by Yamada [19].

The formation of deposits is also affected by the engine operating conditions which translate into the engine operation parameters in the test cycle on the test stand. Such conditions are closely related to the fuel composition and the type of deposit, and thus vary depending on the type of deposits we wish to form in the lab and study.

The operational problems relating to the formation of external and internal deposits in the fuel injectors of CI engines were a motivation to perform the study which results are presented below. The aim was to form the external (coke) deposits and internal organic (amide-type) deposits typical for European fuels, and then to evaluate their impact on the injector operation. The innovative character of our study lies in de- signing a simulation engine test which, in combination with suitably prepared fuels, allowed forming various types of injector deposits on the engine test stand in a short time. The fuel preparation was guided both by our own earlier experiments $[14,16,18]$, and by the composition of deposits determined by other research institutes during the actual operation of vehicles $[12,17,19]$. After the formation of deposits in the HPCR injectors, we evaluated, among other things, the diagnostic parameters of the injectors on a professional test stand in order to determine the impact of these deposits on the operational parameters of fuel injectors.

\section{Materials used in the tests}

In order to accelerate the formation of injector deposits (especially the IDID), the engine was running on the naturally aged, commercially available diesel fuel containing $4.78 \%(\mathrm{v} / \mathrm{v})$ of FAME Table 2. Moreover, added to the fuel as 1-litre premixes were mixtures of chemical compounds which according to the available results of tests performed at various laboratories have the greatest impact on the formation of various IDID $[1,2,6,9,10,11,12,14,16]$. The said

Table 2. Selected physical and chemical properties of fuels used during engine tests

\begin{tabular}{|c|c|c|c|c|}
\hline Tested parameter & Test method & Unit & Diesel fuel & B100 \\
\hline Oxidation stability & PN-EN 15751:2014 & $\mathrm{h}$ & 19.8 & 4.9 \\
\hline Resistance to oxidation & $\begin{array}{l}\text { PN-EN ISO } \\
\text { 12205:2011+Ap1:2011 }\end{array}$ & $\mathrm{g} / \mathrm{m}^{3}$ & 5 & 32 \\
\hline Oxidation stability & ASTM D 7545-14 & minute & 39 & 23 \\
\hline $\begin{array}{l}\text { Corrosion properties to steel: } \\
\text { - temp. } 38^{\circ} \mathrm{C} \text {, test time } 5 \mathrm{~h} \\
\text { - temp. } 50^{\circ} \mathrm{C} \text {, test time } 3 \mathrm{~h}\end{array}$ & $\begin{array}{l}\text { ASTM D 665-14 } \\
\text { Procedure A (distilled } \\
\text { water) }\end{array}$ & - & $\begin{array}{c}\text { brak } \\
-\end{array}$ & $\begin{array}{c}- \\
\text { brak }\end{array}$ \\
\hline Contaminants & $\begin{array}{l}\text { PN-EN 12662:2014 } \\
\text { PN-EN 12662:2009 }\end{array}$ & $\mathrm{mg} / \mathrm{kg}$ & $\begin{array}{c}6.0 \\
-\end{array}$ & $\begin{array}{c}- \\
182.5\end{array}$ \\
\hline Kinematic viscosity at $40^{\circ} \mathrm{C}$ & PN-EN ISO 3104:2004 & $\mathrm{mm}^{2} / \mathrm{s}$ & 3.113 & 4.540 \\
\hline $\begin{array}{l}\text { Distribution of contaminants: } \\
-4,6 \text { and } 14 \mu \mathrm{m} \\
-2 \text { and } 5 \mu \mathrm{m}\end{array}$ & $\begin{array}{l}\text { ISO } 11500: 2008 \text { and } \\
\text { PN-ISO 4406:2005 }\end{array}$ & - & $\begin{array}{c}18 / 16 / 14 \\
18 / 16\end{array}$ & $\begin{array}{c}23 / 23 / 23 \\
23 / 23\end{array}$ \\
\hline $\begin{array}{l}\text { Fractional composition: } \\
\text { - up to temp. } 250{ }^{\circ} \mathrm{C} \text { distils } \\
\text { - up to temp. } 350{ }^{\circ} \mathrm{C} \text { distils } \\
\text { - } 95 \%(V / V) \text { distils up to temp. }\end{array}$ & PN-EN ISO 3405:2012 & $\begin{array}{c}\%(V / V) \\
{ }^{\circ} \mathrm{C} \\
{ }^{\circ} \mathrm{C}\end{array}$ & $\begin{array}{c}29.6 \\
92.6 \\
358.8\end{array}$ & - \\
\hline Density at $15^{\circ} \mathrm{C}$ & PN-EN ISO 12185:2002 & $\mathrm{kg} / \mathrm{m}^{3}$ & 838.8 & - \\
\hline Sulfur content & PN-EN ISO 20846:2012 & $\mathrm{mg} / \mathrm{kg}$ & 7.7 & - \\
\hline Water content & PN-EN ISO 12937:2005 & $\mathrm{mg} / \mathrm{kg}$ & 65 & - \\
\hline Flash point & PN-EN ISO 2719:2007 & ${ }^{\circ} \mathrm{C}$ & 69 & - \\
\hline Cetane number & PN-EN 5165:2014 & - & 52.8 & - \\
\hline Cetane index & $\begin{array}{l}\text { PN-EN ISO } \\
4264: 2010+A 1: 2013-07\end{array}$ & - & 54.1 & - \\
\hline $\begin{array}{l}\text { Cold filter plugging point } \\
\text { (CFPP) }\end{array}$ & PN-EN 116:2015 & ${ }^{\circ} \mathrm{C}$ & -6 & - \\
\hline $\begin{array}{l}\text { Carbon residue from } 10 \% \\
\text { distillation residue }\end{array}$ & PN-EN ISO 10370:2014 & $\%(m / m)$ & 0.048 & - \\
\hline Ash residue & PN-EN ISO 6245:2008 & $\%(m / m)$ & $<0.001$ & - \\
\hline
\end{tabular}


chemical compounds comprised the ingredients present in detergent and lubrication additives, corrosion inhibitors, additives increasing the cetane number and the contaminants which make their way into to the fuel. As a result, two fuels described below were prepared for the simulation engine tests.

In test No. 1, the propensity for the formation of external and internal deposits was tested on the aged, commercially available diesel fuel (physical and chemical properties are given in Table 2) with addition of 120ppm of PIBSI (Polyisobutylene Succinimide) + 100ppm of hydrogenated dimer of oleic acid $+1 \mathrm{ppm}$ of formic acid. This aimed at accelerating the formation of amide deposits by adding PIBSI on which the detergent additives to diesel fuel are based and by adding acidic substances which are ingredients of lubrication additives.

In test No. 2, similarly to test No. 1, the propensity for the formation of external and internal deposits was tested on the aged, commercially available diesel fuel (Table 2) in which the content of biocomponents $(4.78 \%(\mathrm{v} / \mathrm{v})$ FAME) was increased to $10 \%(\mathrm{v} / \mathrm{v})$ by adding aged $\mathrm{B} 100$ (properties given in Table 2). Moreover, $500 \mathrm{ppm}$ of 2 ethyl-hexyl nitrate (2-EHN) $+120 \mathrm{ppm}$ of PIBSI (small molecular mass) were added to the fuel. This aimed at accelerating the formation of amide (polymer-type) deposits by adding PIBSI on which the detergent additives to diesel fuel are based and the formation of ester deposits from aged FAME in tandem with 2 ethyl-hexyl nitrate (2-EHN) added to increase the cetane number.

\section{Test methodology}

The engine simulation tests were performed on a multi-purpose test stand equipped with a modern, widely used HSDI (High Speed Direct Injection) FORD 2.0i 16V Duratorq TDCi diesel engine coupled with an Alpha $160 \mathrm{AF}$ eddy current brake from AVL, with a control module allowing the programming of the engine operation param-

Table 3. Selected technical parameters of the FORD 2.0i 16V Duratorq TDCi engine

\begin{tabular}{|c|c|}
\hline Engine type & four-stroke, compression ignition \\
\hline Fuel injection type & $\begin{array}{l}\text { Direct fuel injection, common rail (Delphi) } \\
\text { electronically controlled, cooperating with the } \\
\text { Levanta engine control system }\end{array}$ \\
\hline Cylinders arrangement & In-line, vertical \\
\hline No. of cylinders & 4 \\
\hline Injection sequence & $1-3-4-2$ \\
\hline Type of timing gear & DOHC/4 VPC \\
\hline Cylinder diameter & $86.0 \mathrm{~mm}$ \\
\hline Piston stroke & $86.0 \mathrm{~mm}$ \\
\hline Displacement & $1998 \mathrm{~cm}^{3}$ \\
\hline Maximum power & $130 \mathrm{KM}(96 \mathrm{~kW})$ at $3800 \mathrm{rpm}$ \\
\hline Max. torque & $330 \mathrm{Nm}$ at $1800 \mathrm{rpm}$ \\
\hline Max. instantaneous speed & $4800 \mathrm{rpm}$ \\
\hline Idle speed & $750 \pm 20 \mathrm{rpm}$ \\
\hline Compression ratio & 18.2 \\
\hline Filling & $\begin{array}{l}\text { turbocharged with intercooler and "overboost" } \\
\text { function }\end{array}$ \\
\hline Valve clearance & Hydraulic adjustment \\
\hline $\begin{array}{l}\text { Capacity of lubrication } \\
\text { system with filter }\end{array}$ & $6.0 \mathrm{dm}^{3}$ \\
\hline $\begin{array}{l}\text { Complies with emission } \\
\text { standard }\end{array}$ & Euro IV \\
\hline
\end{tabular}

Table 4. Parameters of the 4-phase engine cycle

\begin{tabular}{|c|c|c|c|}
\hline Phase & $\begin{array}{c}\text { Time } \\
{[\mathbf{s}]}\end{array}$ & $\begin{array}{c}\text { Engine speed } \\
{[\mathbf{r p m}]}\end{array}$ & $\begin{array}{c}\text { Engine load } \\
{[\mathbf{N m}]}\end{array}$ \\
\hline 1 & 30 & 1000 & $\sim 0$ \\
\hline 2 & 150 & 1800 & 100 \\
\hline 3 & 60 & 3000 & 70 \\
\hline 4 & 60 & 1500 & 50 \\
\hline
\end{tabular}

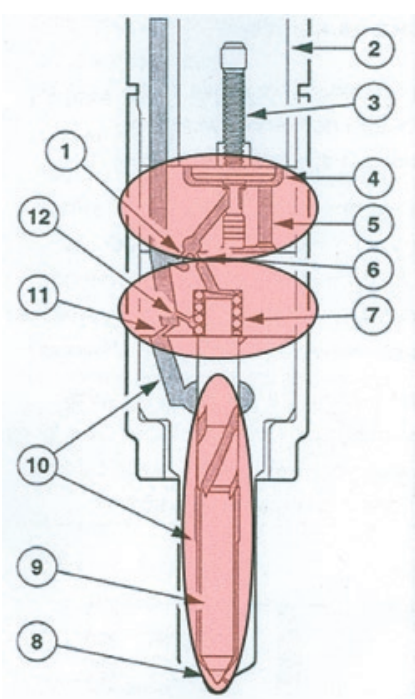

1 - top orifice of control chamber

2 - solenoid valve

3 - solenoid valve spring

4 - valve needle

5 - fuel outflow hole

6 - outflow orifice of control chamber

7 - control chamber

8 - injector holes

9 - injector needle

10 - injector pre-chamber

11 - pre-chamber orifice

12 - bottom orifice of control chamber

Fig. 2. Longitudinal section of the bottom part of an injector with evaluated components marked

eters (rpm and load). The basic technical parameters of the FORD 2.0i 16V Duratorq TDCi are given in Table 3.

The engine tests were performed in a 4-phase, repeatable cycle which reflected the average engine operating conditions in a low-intensity city traffic. The parameters of the 4-phase cycle are given in Table 4.

The test duration was 100 hours of actual engine operation in 8-hour periods which comprised repetitions of the 4-phase cycle (Table 4) and were separated by 16 -hour interruptions during which the formed deposits stabilized.

When the test was complete, the injectors were removed from the engine and two of them were sent for full, professional diagnostics and the other two were left to take photographs of the internal deposits. The necessity for such procedure resulted from the fact that the deposits may be subject to mechanical and chemical damage/changes during the diagnostics and in the final stage they are removed in order to evaluate the parameters and the adjustment possibilities of the "cleaned" injectors. On the other hand, before the diagnostics the injectors must not be dismantled (e.g. for photographing and evaluation of deposits) as this would affect (distort) the diagnostic parameters after the test.

The injector evaluation after the test comprised both the external coke deposits and the IDID. In case of the IDID, the obligatory evaluation was performed on the injector needle, solenoid valve control piston, and control chamber body as components with critical impact on the correct injector operation, and in addition most often subject to damage. The evaluation could have been extended to other components if necessary.

Figure 2 presents components of the HPCR injectors which were evaluated in terms of fouling with the IDID.

The measurements and evaluations of selected diagnostic parameters were performed on the Zapp CRU.2i testing device. The evaluations of each diagnostic parameters are an average value from three measurements. 
The test of each injector involved a measurement of a number of different parameters, and then their evaluation in relation to permissible and limit deviations typical for an injector in full good working order, and permissible deviations for an injector in use specified by its manufacturer. Figure 5 presents a list of evaluations of six selected parameters of tested injectors. In addition, each evaluation is presented on a small graph of a parameter of the tested injector in relation to permissible deviations of an injector in full good working order (broken lines) and limit, permissible deviations of an injector in use (full lines). The graphs of parameters of injectors in full good working order were marked in blue, and the parameters outside the permissible limits for injectors in full good working order (but not excluding further use and not requiring repair) were marked in green, and the red colour indicates the

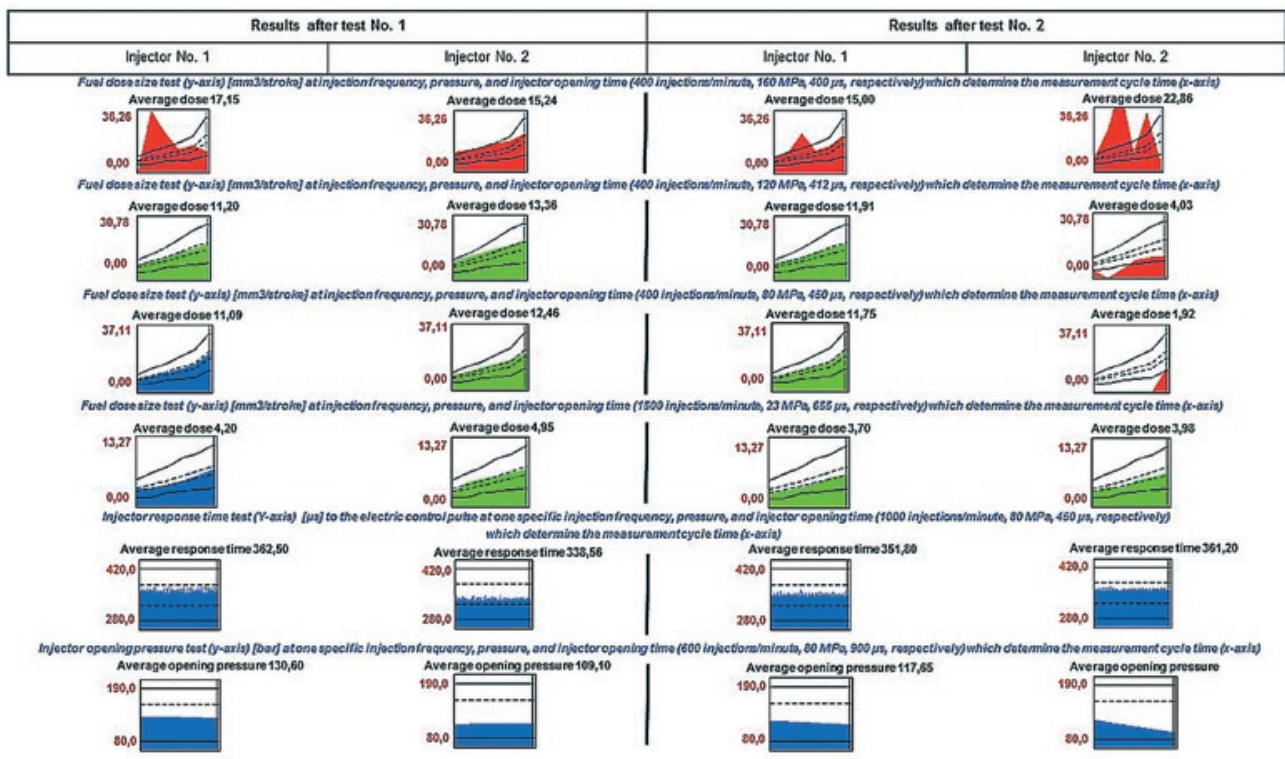

Fig. 5. Diagnostic evaluation results of FORD Duratorq 2.0 TDCi injectors after test No. 1 and 2 injector parameters outside the permissible tolerances for injectors in use. Such injectors with parameters marked in red must be cleaned and/or repaired and then readjusted.

\section{Test results}

Figure 3 presents the tips of injectors after test No.1.

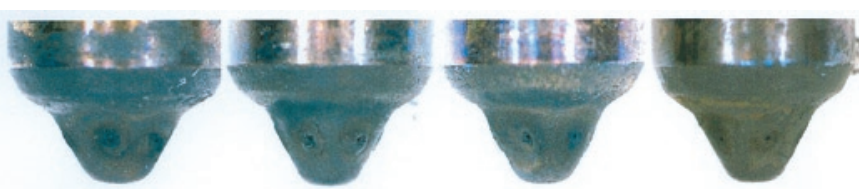

Fig. 3. Photographs of injector tips from FORD Duratorq 2.0 TDCi after test No. 1

a)

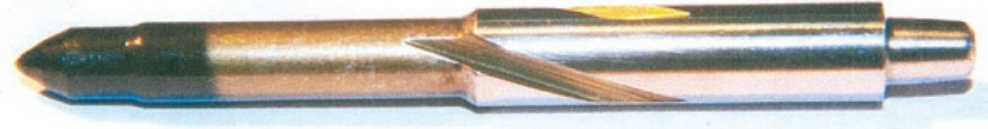

b)

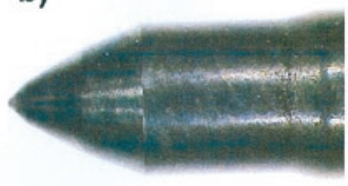

d)

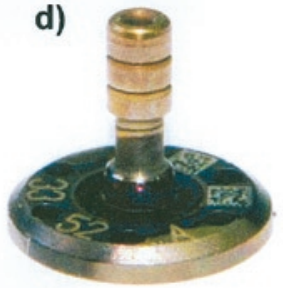

e)

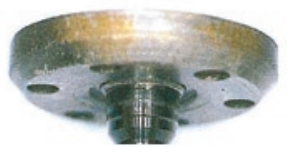

Fig. 4. Images of selected internal parts of the HPCR injectors a) injector needle, b) conical end of injector needle, c) guiding part of injector needle, $d, e, f)$ piston of fuel flow control valve
The injector tips have quite thick layers of uniform, mat, dry, dark brown deposits. The deposits are thicker around the fuel outlet holes. The peeling of deposits is present in some areas - Figure 3 . The size and distribution of deposits on the evaluated surfaces is similar. Figure 4 shows selected internal parts of injectors after test No. 1.

Particularly intensive deposits, covering the surfaces in an irregular manner, were found on the conical ends of injector needles and on the cylindrical part of needles directly above the conical part Fig. 4 a, b. More uniform amide deposits, although of varying thickness, covered the internal surfaces of grooves in the cylindrical guiding part of the needle, and plungers and heads of pistons of the fuel flow control valves - Fig. 4. c, d, e, f.

The next part of the evaluation comprised a measurement of selected diagnostic parameters of two injectors after test No. 1.

The injectors evaluations from both tests presented in Fig. 5 indicate that after test No. 1 the upper limit values of dosed fuel were significantly exceeded at the injection pressure of $160 \mathrm{MPa}$ and the injector opening time of $400 \mu \mathrm{s}$. As a result, from the point of view of operational parameters, the injectors were not fit for further use without maintenance-repair operations comprising washing, adjustment and possibly replacement of some internal parts. In addition, there were lesser, permissible deviations in fuel doses at other pressures and injector opening times. This concerned one measuring range in case of injector No. 1 and all measuring ranges in case of injector No. 2 - Fig. 5. The most probable reason of such deterioration of the injectors' diagnostic parameters were internal deposits formed on the working part of the needle which slides on the injector body, and on the plunger of the fuel flow control piston inside the injector. This changed the injector operation time as a result of a delayed or slowed down response of the needle to the electric control pulse, and even caused a possibility of the needle's hanging in the injector body.

Fig. 6 presents the tips of injectors after test No.2.

Mat, dark grey, peeling deposits or varying thickness were formed on the injector tips. The deposits were slightly thicker around the fuel outlet holes - Fig. 6. Figure 7 shows selected internal parts of injectors after test No. 2 .

Intensive amide (polymer) deposits accompanied by ester deposits were formed on the injectors inside surfaces. A particularly large amount of deposits was found on conical ends 

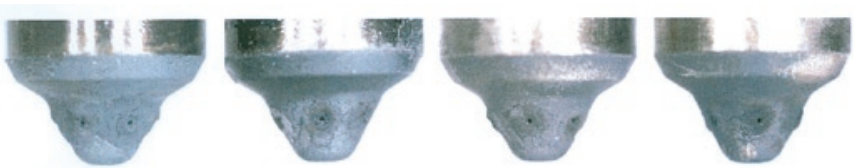

Fig. 6. Photographs of injector tips from FORD Duratorq 2.0 TDCi after test No. 2

of injector needles and on the cylindrical part of needles above the conical part. These deposits had an irregular shape and colour changing from yellow through orange, brown to dark brown. - Fig. 7 b. Intensive polymer deposits were found on the cylindrical parts of the needle washed with fuel, and in grooves in the cylindrical guiding part of the needles, and also in grooves of plungers of the fuel flow control pistons - Fig. $7 \mathrm{c}$, d, e. The sliding, cylindrical surfaces of needles and plungers feature areas where the deposits were mechanically rubbed during the injector operation - Fig. $7 \mathrm{~d}$, e.

a)

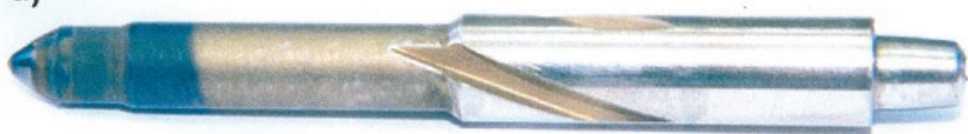

b)

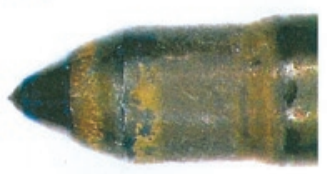

c)

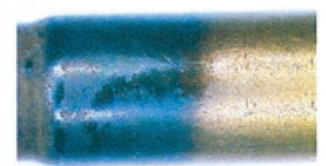

d)

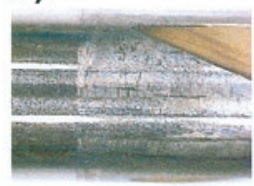

e)

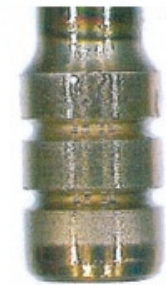

f)

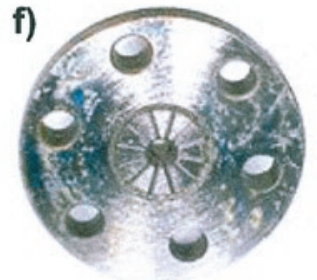

Fig. 7. Images of selected internal parts of the HPCR injectors a) injector needle, b) conical end of injector needle, c) cylindrical part of injector needle washed with fuel, d) guiding part of injector needle, e, f) piston of fuel flow control valve

Graphical results of evaluation of injectors from the FORD Duratorq 2.0 TDCi engine after test No. 2 are presented in Fig. 5.

Similarly to test No. 1, in both injectors the upper limit values of dosed fuel were significantly exceeded at the injection pressure of $160 \mathrm{MPa}$ and the injector opening time of $400 \mu \mathrm{s}-$ Fig. 8 .

In case of injector No. 2, the lower limit values of dosed fuel were also exceeded beyond the permitted tolerances at the injection pressure of $120 \mathrm{MPa}$ and the injector opening time of $412 \mu \mathrm{s}$, and at the injection pressure of $80 \mathrm{MPa}$ and the injector opening time of $450 \mu \mathrm{s}-$ Fig. 5. For the same parameters, the deviations in injector No. 1 were lesser, within the tolerance limits. The summary evaluation showed however that both injectors were not fit for further use without maintenance-repair operations comprising washing, adjustment and possibly replacement of some internal parts.

Similarly to test No. 1, the most probable reason of such deterioration of the injectors' diagnostic parameters were internal deposits formed on the working part of the needle which slides on the injector body, and on the plunger of the fuel flow control piston inside the injector. This changed the injector operation time as a result of a delayed or slowed down response of the needle to the electric control pulse, and even caused a possibility of the needle's hanging in the injector body.

\section{Conclusions}

- The formation of deposits in fuel injectors of the CI engines is influenced by many simultaneously interacting factors. In many cases, specific factors have opposite effects on various groups (types) of deposits, initiating and intensifying the formation of some and at the same time reducing the formation of others.

- The number and complexity of the factors influencing the formation and growth of the IDID in the HPCR injectors of the CI engines still requires more investigation into the their significance and mechanisms of cooperation.

- The IDID formed during the tests caused typical dysfunctions of the HPCR injectors observed during actual operation of vehicles, sometimes making further use impossible.

- The progress in the area of design and technology of the piston combustion engines and the fuel injection systems used in them, as well as the changing fuel production technologies will require the development and use of increasingly more effective detergent additives of multidirectional action. In addition to the design modifications of injectors, such additives are the most effective means to prevent the formation of external and internal injector deposits.

- The evaluation of diagnostic parameters of the HPCR injectors allowed a widened, precise determination of injector dysfunctions caused by the formed deposits.

\author{
Abbreviations \\ CFI Cold Flow Improver \\ EDS Energy Dispersive X-Ray Spectroscopy \\ 2-EHN 2 Ethyl-Hexyl Nitrate \\ FAME Fatty Acid Methyl Esters \\ FT-IR Fourier Transform Infrared Spectroscopy \\ GDI Gasoline Direct Injection \\ HPCR High Pressure Common Rail \\ HSDI High Speed Direct Injection \\ IDID Internal Diesel Injector Deposit \\ MPFI Multi Port Fuel Injection \\ PAH Polynuclear Aromatic Hydrocarbons \\ EGR Exhaust Gas Recirculation \\ PIBSI Polyisobutylene Succinimide \\ SEM Scanning Electron Microscopy \\ SPI Single Point Injection \\ PCV Positive Crankcase Ventilation \\ EDM Electrical Discharge Machining \\ SI Spark Ignition \\ CI Compression Ignition
}




\section{References}

1. Baker J, Cook S. Sodium Contamination of Diesel Fuel, its Interaction with Fuel Additives and the Resultant Effects on Filter Plugging and Injector Fouling. 2013; SAE 2013-01-2687.

2. Baker J, Snape C, Scurr D. Diesel Deposits. 2013; 9th International Colloquium Fuels Conventional and Future Energy for Automobiles. 15-17 January 2013.

3. Brigel A, Ladommatos N, Aleiferis P, Zülch S, et al. Deposit Formation in the Holes of Diesel Injector Nozzles: A Critical Review. 2008; SAE Technical Paper No. 2008-01-2383.

4. Birgel A, Ladommatos N, Aleiferis P, Milovanovic N, Lacy P, Richards P. Investigations on Deposit Formation in the Holes of Diesel Injector Nozzles. 2011; SAE 2011-01-1924.

5. Caprotti R, Breakspear A, Graupner O, Klaua T. Diesel Injector Deposits Potential on Future Fuelling Systems. 2006; SAE Technical Paper No. 2006-01-3359.

6. Caprotti R, Bhatti N, Balfour G. Deposit Control in Modern Diesel Fuel Injection Systems. 2010; SAE Technical Paper No 2010-01-2250.

7. Fang H L, McCormick R L. Spectroscopic Study of Biodiesel Degradation Pathways. 2006; SAE Technical Paper No.2006-01-3300.

8. Iida Y. Biodiesel Studies in Japan. 2012; CEN/TC19/WG24, 22 May 2012.

9. Lacey P, Gail S, Kientz J M, Milanovic N, Gris C. Internal Injector Deposits. 2011; SAE Technical Paper No. 2011-01-1925.

10. Quigeley R, Barbour R, Fahey E, Arters D, Wetzel W, Ray J. A Study of The Internal Diesel Injector Deposit Phenomenon. 2009; TAE Fuels 7th Annual Colloquium - 2009.

11. Quigley R, Barbour R, Arters D, Bush J. Understanding the Spectrum of Diesel Injector Deposits. 2013; 9th International Colloquium Fuels Conventional and Future Energy for Automobiles. 15-17 January 2013.

12. Reid J, Barker J. Understanding Polyisobutylene Succinimides (PIBSI) and Internal Diesel Injector Deposits. 2013; SAE Technical Paper No. 2013-01-2682.

13. Shiotani H, Goto S. Studies of Fuel Properties and Oxidation Stability of Biodiesel Fuel. 2007; SAE Technical Paper No. 2007-01-0073.

14. Stępień $Z$. The reasons and adverse effect of internal diesel injector deposits formation-Przyczyny powstawania i szkodliwy wpływ wewnętrznych osadów we wtryskiwaczach silników o zapłonie samoczynnym. Combustion Engines (Silniki Spalinowe) 2014; 1 (156) : 20 - 29.

15. Stępień Z. Investigations of injector deposits in modern diesel engines - Badanie osadów wtryskiwaczy nowoczesnych silników z zapłonem samoczynnym. Combustion Engines (Silniki Spalinowe), 2016; 2 (165) : 9 - 20.

16. Stępień Z. Ewolucja metodyki oceny zanieczyszczenia rozpylaczy silników o zapłonie samoczynnym. Nafta-Gaz, $2014 ; 10$ : $707-716$.

17. Tanaka A, Yamada K, Omori T, Bunne S, Hosokawa K. Inner Diesel Injector Deposit Formation Mechanism. 2013; SAE 2013-01-2661

18. Urzędowska W, Stępien Z. Prediction of threats caused by high FAME diesel fuel blend stability for engine injector operation -Fuel Processing Technology 2016; 142: 403-410. https://doi.org/10.1016/j.fuproc.2015.11.001.

19. Yamada K, Bunne S, Omori T. Diesel Injector Deposit. 2015 Powertrains, Fuels and Lubricants Meeting TWS2 2nd, September, 2015.

20. Żak G, Ziemiański L, Stępień Z, Wojtasik M. Problemy związane z tworzeniem się osadów na elementach układów wtryskowych nowoczesnych silników Diesla - przyczyny, metody badań, przeciwdziałanie. Nafta-Gaz 2013; 9: 702 - 708.

\section{Zbigniew STĘPIEŃ}

Oil and Gas Institute - National Research Institute

Lubicz 25 A, 31-503 Krakow, Poland

E-mail: stepien@inig.pl 